\title{
荷重体としての物体の機械的荷重体への同定方法の提示
}

物体が与える動的荷重による架構式床の破損の評価方法に関する研究（その 1)

\section{PRESENTATION OF THE SUBSTITUTION METHOD OF LOADS AFFECTED BY PHYSICAL BODIES TO THAT OF MECHANICAL LOADING SYSTEMS \\ Study on the evaluation method of fracture of framed floors under dynamic loads affected by physical bodies (Part 1)}

\section{小野英哲*1, 高橋 宏 樹*2, 井戸川 純子*3, 菊池 純 子*4, 崔 寿 炗*5 \\ Hidenori ONO, Hiroki TAKAHASHI, Junko IDOGAWA, Junko KIKUCHI and Soo Kyung CHOI}

\begin{abstract}
The purpose of this study is to establish the evaluation method of the fracture of framed floors under dynamic loads affected by physical bodies.

First, we measured dynamic loads affected by rigid steel bodies, and showed relations between maximum loads and masses of rigid steel bodies under each condition (stiffness of framed floor and falling height). relation.

Next, we measured dynamic loads affected by some physical bodies, and obtained each actual mass by means of the

As a result, in this paper part 1 , we presented the substitution method of loads affected by that of physical bodies to mechanical loading systems.
\end{abstract}

keywords: dynamic loads by physical bodies, substitution method, framed floors, fracture, evaluation method, mechanical loading system 物体が与学動的荷重, 同定方法, 架構式床, 破損, 評価方法, 機械的荷重体

1. 序

近年, 建築物床は, フリーアクセスフロアなどにみるごとく架構式構 法により構成されることが従来より多く,これらの床には, 施工性の向 上, 自重の軽減などの観点で軽量化，接合方法の簡易化などが強く 望まれている。

一方，軽量化，接合方法の簡易化などを計る前提条件として所定の 耐力の確保が必要不可久となるため, より合理的な耐力設定が重要な 課題となっている。

耐力設定の一つの指標となる架構式床 (以降, 単に床と呼ぶ) の耐 力判定方法に関して,これまで，国内外で様々な提案がなされ，我が 国でも, JIS A ${ }^{1) 22}$ などに, 静的荷重および動的荷重に対する耐力判 定方法が定められている。

しかしながら, 動的荷重に対する耐力判定方法に関しては, 特に負 荷される動的荷重に関し，実際との関連が十分には吟味されていない， 破損の検出方法が定量的, 客観的でない, などの理由で, 様々な動 的荷重に対する妥当な評価ができるとは言い難く, 動的荷重に対する 耐力不足による破損が発生したり，逆に過剩な耐力をもつ不合理な床 が開発されるなどの問題が解決されない状況にある。

動的荷重は大きく人間および物体により負荷されると考えられるが,
著者の一部らは，すでに人間が与える動的荷重による架構式床・壁の 破損の評価方法に関して考究した結果を報告している( ${ }^{3) \sim 5)}$

本研究は, 物体が与える動的荷重による床の破損の評価方法を提 示しようとするもので, 本論文はそのうち特に重要となる荷重体として の物体を機械的荷重体へ同定する方法および結果を述べるものであ る。

なお, 本論文の概要は平成 9 年度日本建築学会大会に発表済みで ある゙。

\section{2. 本研究の目的と範囲}

本研究の最終目的は，物体が与える動的荷重による床の破損を定 量的に評価できる方法を提示することにある。

このうち, 本論文では, 動的荷重を与える観点で複雑な様相をもつ 様々な物体をより簡易な機械的荷重体一同定する方法を検討すること を目的とする。

なお，同定された機械的荷重体を用いて床の破損を定量的に評価 する方法に関しては次稿に発表する予定である。

また, 物体が与える動的荷重による床の破損の定量的評価に関す る課題では, 荷重体あるいは荷重条件の設定が最も重要で, かつ, 国

\footnotetext{
*1 東京工業大学工学部建築学科 教授 · 工博

*2 東京工業大学工学部建築学科 助手・博士 (工学)

*3 東京工業大学 大学院生・修士 (工学)

*4 株式会社大林組 (当時東京工業大学:)

*5 建国大学校 非常勤講師・博士 (工学)
}

Prof., Dept. of Architecture and Building Engineering, Faculty of Engineering, Tokyo Institute of Technology, Dr. Eng.

Research Assoc., Dept. of Architecture and Building Engineering, Faculty of Engineering, Tokyo Institute of Technology, Dr. Eng.

Graduate Student, Tokyo Institute of Technology, M. Eng.

Obayashi Corporation

Part-time Lecturer, Konkuk University, Dr. Eng. 
内外においてこれまで, 明確な筋道のもとに設定された例は皆無であ ることを付記する。

さらに, 人間や物体による動的荷重を建築分野では一般に衝撃荷 重としているが, 著者の一部らの研究 ${ }^{3)}{ }^{4) .51 .12)}$ において, 衝撃の定義 を利用できない小さな速度であることを明らかにしているので, 本研究 では既往の研究に関して論ずる場合以外は動的荷重と呼ぶこととする。

\section{3. 既往の研究}

床の耐衝撃性に関する既往の研究は, 大きく, 人間が与える動的荷 重による場合と物体が与える動的荷重による場合に分けられる。こう ち, 人間が与える動的荷重による破損の評価方法に関しては, 著者の

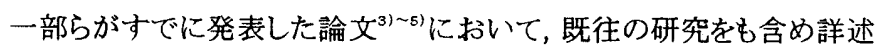
しているので, 本論文では割愛する。

物体が与える動的荷重による床の破損に関連する研究はいくつか あるが, 大きくは，物体の速度，相当質量を何らかの方法で求めてい

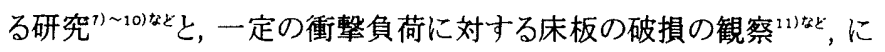
分けられる。いずれも貴重な知見を提示してはいるが, 物体による負 荷と設定した荷重体あるいは荷重条件との近似性, さらには, 破損の 定量的検出方法に関しては, より厳密な検討が必要とされるがなされ ておらず，いまだ妥当な評価方法の提示までには至ってないといえる。

その他, 床以外に物体の衝突による壁, ボード類の耐衝撃性を論じ た研究や規格も数多くみられる。しかし，いずれも厳密にはその妥当 性が検討されていない鋼製錘や砂袋による破損を取扱っているもので, 材料や部材の品質管理の手法としては有効とも考えられるが, 動的荷 重による床の破損の定量的把握を目的と寸る本研究への適用には無 理があるといえる。

\section{4. 本研究における動的荷重の同定方法の宜子}

4.1. 既往の研究におけるおもな方法

4.1.1 運動量保存則を適用する方法 ${ }^{7)+2}$

物体 (質量 $\mathrm{m}_{1}, \mathrm{~m}_{2}$, 衝突直前の速度 $\mathrm{v}_{1}, \mathrm{v}_{2}$, 衝突直後の速度 $\mathrm{v}_{1}^{\prime}$, $\mathrm{v}_{2}^{\prime}$ ) が衝突するとさには運動量が保存されるという(1)式に示す関係を 用い,

$\mathrm{m}_{1} \mathrm{v}_{1}+\mathrm{m}_{2} \mathrm{v}_{2}=\mathrm{m}_{1} \mathrm{v}_{1}{ }^{\prime}+\mathrm{m}_{2} \mathrm{v}_{2}{ }^{\prime}$

両者の衝突前後の速度 $\mathrm{v}_{1}, \mathrm{v}_{2}, \mathrm{v}_{1}{ }^{\prime}, \mathrm{v}_{2}{ }^{\prime}$ を計測し，物体の相当質量 $\mathrm{m}_{1}$ $=\mathrm{m}_{2}\left(\mathrm{v}_{2}-\mathrm{v}_{2}{ }^{\prime}\right) /\left(\mathrm{v}_{1}{ }^{\prime}-\mathrm{v}_{1}\right)$ を求める同定方法であるが, 2 つの物体の反 発係数や衝突時の変形量などを求めるのが困難なため, 相当質量の 絶対值を求めることは極めて困難といえる。

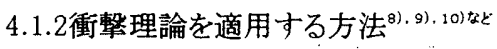

速度 $v$ の物体が衝突時に対象に与える最大荷重 $F$ と作用時間 $\Delta \mathrm{t}$ の 関係を求め, 運動量と力積が等しいといら(2)式に示す関係を用い，

$$
\int_{0}^{\Delta t} F d t=m v
$$

物体の相当質量mを求める同定方法である。しかし，現実には荷重 $\mathrm{F}$ を真の值として求めるのが非常に困難なこと, 少なくとも本研究の範囲 での $\Delta \mathrm{t}$ の值はいわゆる衝撃現象の場合と比較して極めて大きすぎる ため衝撃理論から誘導される(2)式の適用が不適切なのが実証され ていることからら ${ }^{3)}$ (4),5), 12), 本方法は適切ではないといえる。 4.1 .3 与えられる荷重と近似する荷重を機械的荷重体により再現する

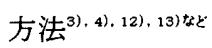

$4.1 .1,4.1 .2$, の場合のように理論的に仮説を立てて物体の相当質 量などを求めるのではなく, 物体により与えられる動的荷重と同等の動 的荷重を具現するような機械的荷重体を一般には試行錯誤的に求め る同定方法である。動的荷重は, 物体さらには床側の特性により大きく 変化するなど複雑な様相を呈するので, 4.1.1, 4.1.2で述べたように論 理的に求めることは困難なことから, 本方法は近年よく用いられる方法 である。

しかし, 本方法はそれぞれの研究目的の範囲内での妥当性は確保 される点で好都合な方法ではあるが, 同定される荷重体あるいは荷重 条件の汎用性に関しては注意哚く検討寸る必要がある。

4.2. 本研究における同定方法の基本的考え

\subsection{1 本研究で対象とする動的荷重}

床に破損を生じさせるような物体による動的荷重は，大きく，搬送車 などによるもの, 物体の衝乫によるもの,に分けられる。

このうち，搬送車などによる過大な動的荷重が作用することがあらか じめ床の設計条件となる場合は非架構式床つまり相対的に剛な下地 床からなる塗り床, 張床とすることが多く, 本研究で対象とする架構式 床の破損が問題となるのは極めて稀なことから，搬送車などによる動 的荷重は対象外とし, 本研究では日常最も問題となる頻度の高い物 体の衝突による動的荷重を対象にすることとした。

4.2 .2 動的荷重を与える物体と同定する機械的荷重体との関係につ いての基本的考光

床に破損を発生させるような動的荷重を与える物体は, 厳密にはあ る質量を持つ粘弾性体と見なすべきであるが，一般には人体などと比 較して相対的に剛な物体といえるため床の破損に対する効果の観点 からは，4.1.に述べた既往の研究における考え方と同様に, 本研究に おいても物体の場合と同等の大きさの動的荷重を床に与える相当の 質量を持つ㓮な物体を軸とする機械的荷重体として同定できるといえ る。

つぎに, 床の破損に対する効果として質量の他に, 衝突速度，およ び荷重の作用時間, さらに接触部の形状, を考慮する必要がある。 このうち, 衝突速度に関しては, 本研究において物体の実際の衝突速 度をその都度同定する機械的荷重体の衝突速度として取り入れること で解決できることになる。

また, 相対的に剛とみなせる物体の衝突によって生ずる荷重の作用 時間は床側の動的挙動特性および衝突速度に大きく依存すると考え てよく，物体による差異は相対的に極めて少ないと考えてよい。すなわ ち, 同定される機械的荷重体の衝突速度を物体の速度と同一にする ことを前提とすれば, 本研究において床の破損の観点では物体と機械 的荷重体による作用時間の微少な差異を問題とする必要はないとい える。

さらに, 床と接触する部分の物体の形状は床の破損に大きな影響を 及ぼすが，休の破損の観点から最も不利な状況に同定すれば問題は ないことから, 本研究においては床と接触する部分を点接触とするよう 同定される機械的荷重体の床との接触部 (以降へッドと呼ぶ)の形状 を球形とすることで解決できるといえる。

\section{3. 本研究にお泫同定方法の骨子}

4.2.に述べた基本的考え方に基づき設定した同定方法は基本的に は4.1.3に述べた方法とするがその骨子は以下のとおりである。 。実情の床の剛性, 質量などの力学的諸性状に近似した系を持う荷 
重測定装置を用い, 球形ヘッドを具備した鋼製重鍾(以降重錘と呼 ぶ)を軸とする機械的荷重体を所定の高さからの自由落下により衝 乫させた時の最大荷重を求め, 図1に示す実線の関係を求める。 。次に, 実際の物体を同一の高さからの自由落下により荷重測定装 置に衝突させた時の最大荷重Pmaxを測定し，図1を用いて，点線 の経路で同等の最大荷重を発生させる重鍾の質量つまり相当質量 miを求める。

なお, 所定の高さからの自由落下としたのは本論文の段階における 実験を簡易にするためであり所定の衝突速度と置き換えても何ら差し さわりがないことを付記す る。

以上が物体による動的荷 重を同等の動的荷重を発 生させる機械的荷重体へ同 定する方法の骨子である。 ここで留意すべき点は， 物体あるいは機械的荷重体 の衝突によって発生する動 的荷重の諸性状は荷重測

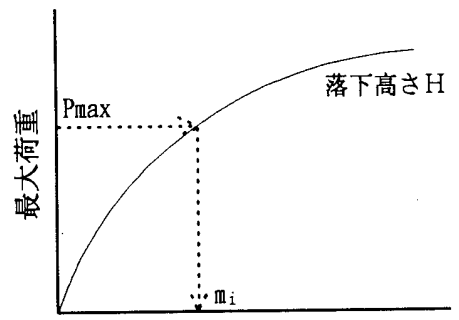

重錘質量

図1 同定の概念図
定装置の力学的諸性状および荷重検出方法に大きく依存するので,

。荷重測定装置の㣚性, 質量等の力学的諸性状はできる限り実情の 床に近似させること,

。同定は設計・試作する荷重測定装置を媒体として行うこと,つまり設 計・試作する荷重測定装置は本研究においてのみ同定の媒体とな り得るクローズドシステムであり, 得られる最大荷重などの値を普遍 性のある絶対值として理解しないこと，

にある。

従来の研究においては，ほぼ同様の方法で得られた動的荷重など の值を絶対的な值さらには一般性のある值として理解しているものが 多いが, 大きな誤りであり，設計した荷重測定装置の力学的諸性状お よび荷重検出方法の条件下での限定された值として理解すべさこと， ただし，同定される機械的荷重体は普遍性のある荷重体であること， を強調したい。

\section{5. 重鍾による動的荷重の測定}

\section{1. 荷重測定装置の概要}

図2に設計・試作した荷重測定装置の概要を示す。本装置は設計 許容荷重 $2000 \mathrm{kgf}$ (最大能力 $3000 \mathrm{kgf}$ ) の動的荷重測定装置で, 荷重受 板, 荷重変換器, 梁および移設が可能なピン, 基台で構成され, 荷重 受板の中央部分に重鍾あるいは物体によって載荷された荷重は荷重 受板に直結されている4つの荷重変換器によって動的に検出できるよ うになっている。

おもに梁の撓みで具現する荷重受板部分の剛性は床の剛性の差 による動的荷重の差異を検討できるように下記のように実情の床の剛 性の範囲を包含するように3種類とし, ピンで支持されるスパンで調節 できるようになっている。

$$
\begin{array}{cc}
\text { スパン } 615 \mathrm{~mm} & \text { 静的撓み刷性 } \mathrm{Ka}=1677 \mathrm{kgf} / \mathrm{cm} \\
\text { スパン } 880 \mathrm{~mm} & \text { 静的撓み剛性 } \mathrm{Kb}=700 \mathrm{kgf} / \mathrm{cm} \\
\text { スパン } 1080 \mathrm{~mm} & \text { 静的撓み剛性 } \mathrm{Kc}=287 \mathrm{kgf} / \mathrm{cm} \\
& \text { *静的撓み用性:直径 } 70 \mathrm{~mm} \text { の載荷板による值 }
\end{array}
$$

また, 合板で構成される荷重受板の表面には $5 \mathrm{~mm}$ 厚の鉄板を貼り
付けさらに $3 \mathrm{~mm}$ 厚の塩化ビニルシートを貼付して実際の床の表面性 状に近似させると同時に, 重鍾あるいは物体の衝突により, 荷重受板 の表面が破壊しないように工夫している。

なお, 塩化ビニルシートは常に取り換えることにより荷重受板の力学 的性状が変化しないようにしている。

また，重鍾あるいは物体の衝突により挙動する荷重受板および梁の 重量は, 約 $25 \mathrm{~kg}$ (スパン $1080 \mathrm{~mm}$ の場合)から約 $15 \mathrm{~kg}$ (スパン $615 \mathrm{~mm} の$ 場 合)で実際の床の有効質量 (載荷時に挙動する部分の質量)に近似し た值としている。
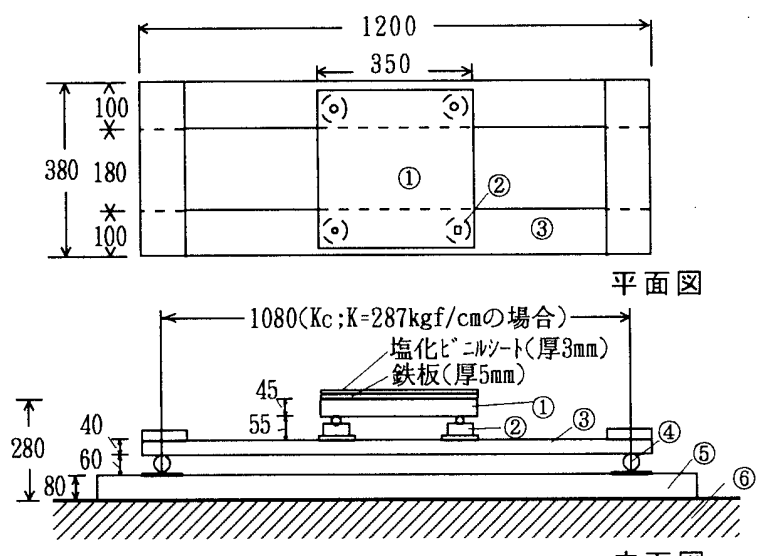

(1)荷重受板 (合板 + 鉄板 + 塩化ビニルシート) 立面図 (2) 荷重変換器 (3)梁(合板)

(4) ピン(鋼製 $\Lambda^{\circ}$ イプ )(5)基台(合板)(6)基盤（単位; mm)

\section{図2 荷重測定装置の概要}

5.2. 重鍾および落下高さ

重錘は鋼製で図3に示すようにへ ッド (曲率半径 $25 \mathrm{~mm}$ ) を持つ質量可 変の機構をもつもの(鋼製プレートを 増減することにより質量を増減する機 構)で, 電磁石の開閉により所定の高 さから荷重受板中央部分に自由落下 するものである。

重錘の質量と落下高さの組み合わ せは実情の物体の落下を想定して表

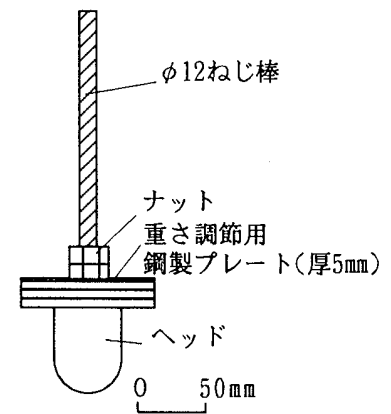

図3 重鍾の概要(2kgの例) 1 のように設定した。なお，本論文の段階では同定方法の骨子を提示

\begin{tabular}{|c|c|c|c|c|c|c|}
\hline \multirow{2}{*}{$\begin{array}{c}\text { 重錘質量 } \\
(\mathrm{kg})\end{array}$} & \multicolumn{6}{|c|}{ 落下高さ（c m) } \\
\hline & 5 & 20 & 40 & 60 & 80 & 100 \\
\hline 0.89 & 0 & 0 & 0 & 0 & 0 & 0 \\
\hline 1.00 & 0 & 0 & 0 & 0 & 0 & 0 \\
\hline 2.00 & 0 & 0 & 0 & 0 & 0 & 0 \\
\hline 3.10 & 0 & 0 & $\mathrm{O}$ & 0 & $\mathrm{O}$ & 0 \\
\hline 4.00 & 0 & 0 & 0 & 0 & 0 & 0 \\
\hline 5.85 & 0 & 0 & 0 & & & \\
\hline 11.40 & 0 & 0 & & & & \\
\hline
\end{tabular}
するもので, 質量と落下高さの厳密な設定は実情を大きく逸脱しない 範井であれば不必要であることを付記する。

\section{表 1 重鍾質量と落下高さの組み合わせ}

5.3. 測定経過および結果

荷重測定装置を用いて重錘による動的荷重を測定した。 実験概要を写頁1に示す。

図4に動的荷重・時間曲線の例を示すが典型的な衝撃的波形を示 しており，破損の観点から最も重要と考える荷重の最大值(最大荷重 


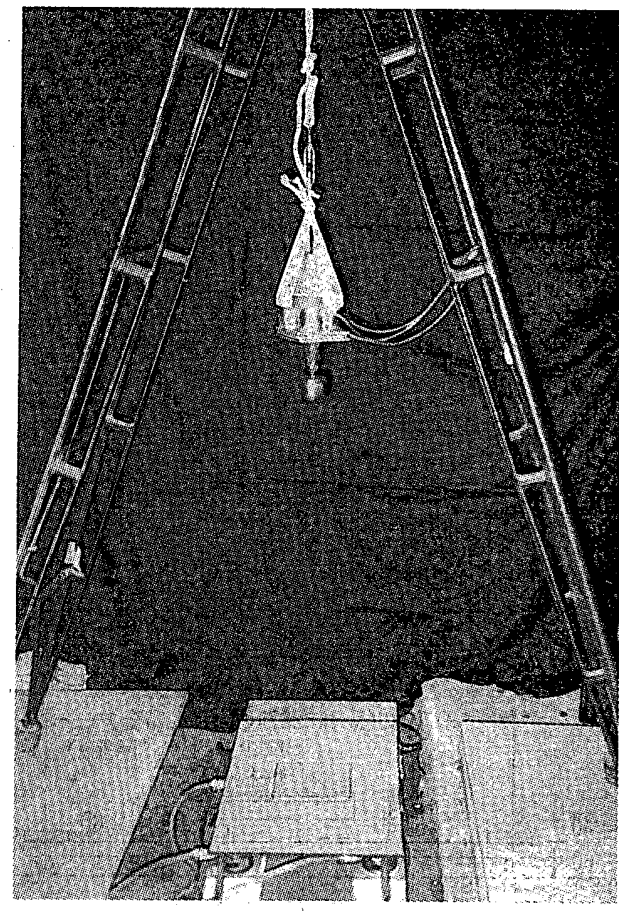

写真 1 実験状況

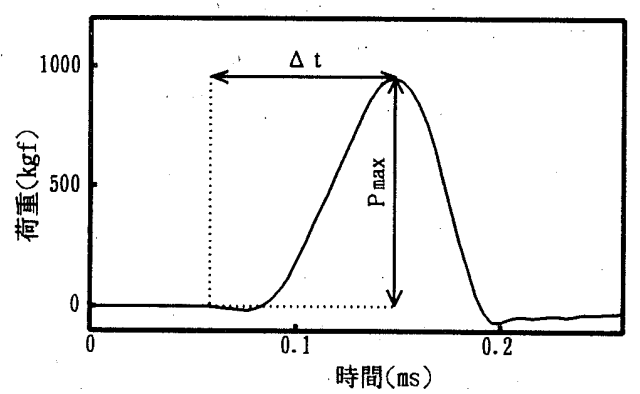

（重銼質量 $2 \mathrm{~kg}$, 落下高さ $40 \mathrm{~cm}$ ，荷重受板部分の粑性 $287 \mathrm{kgf} / \mathrm{cm}$ )

图4動的荷重·時間曲線の例

Pmaxと呼ぶ)も明確に読みとれる。

\section{4. 最大荷重と重鍾質量との関係}

図5に荷重測定装置の剛性 $(\mathrm{Ki})$ ごとに最大荷重( $\mathrm{Pmax})$ と重鍾質量 (m)の関係を示す。

今, 荷重測定装置の力学系を剛性Kなる単純梁と見なした場合, 質 量Mの重錘の高さHからの衝突により発生する荷重Pは, エネルギー の等価交換の関係からごく単純には(3)式のように表せ, 最大荷重P 重鍾質量の関係はKとHを一定とした場合指数関数的な関係になる。

$$
\mathrm{P}=\sqrt{2 \mathrm{KMg} \mathrm{H}}
$$

図5を見ると，いずれの場合も最大荷重Pmaxと重鍾質量 $\mathrm{m}$ の関係 は指数関数的な関係にあり, 単純な理論から導かれる(3)式と同じ傾 向になっているといえる。

また, Pmaxは荷重測定装置の剛性 $(\mathrm{Ka} \sim \mathrm{Kc})$, 重鍾質量および落 下高さの增加とともに増大しており，(3)式で表される傾向と同じ傾向に あることがわかる。

なお，(3)式におけるPは重鍾と梁との接触面で検出される荷重であ り, 本測定の場合は荷重受板の下端で検出される荷重で, 本質的に は異なる荷重といえるが，両者は比例関係にあると見なせることから，

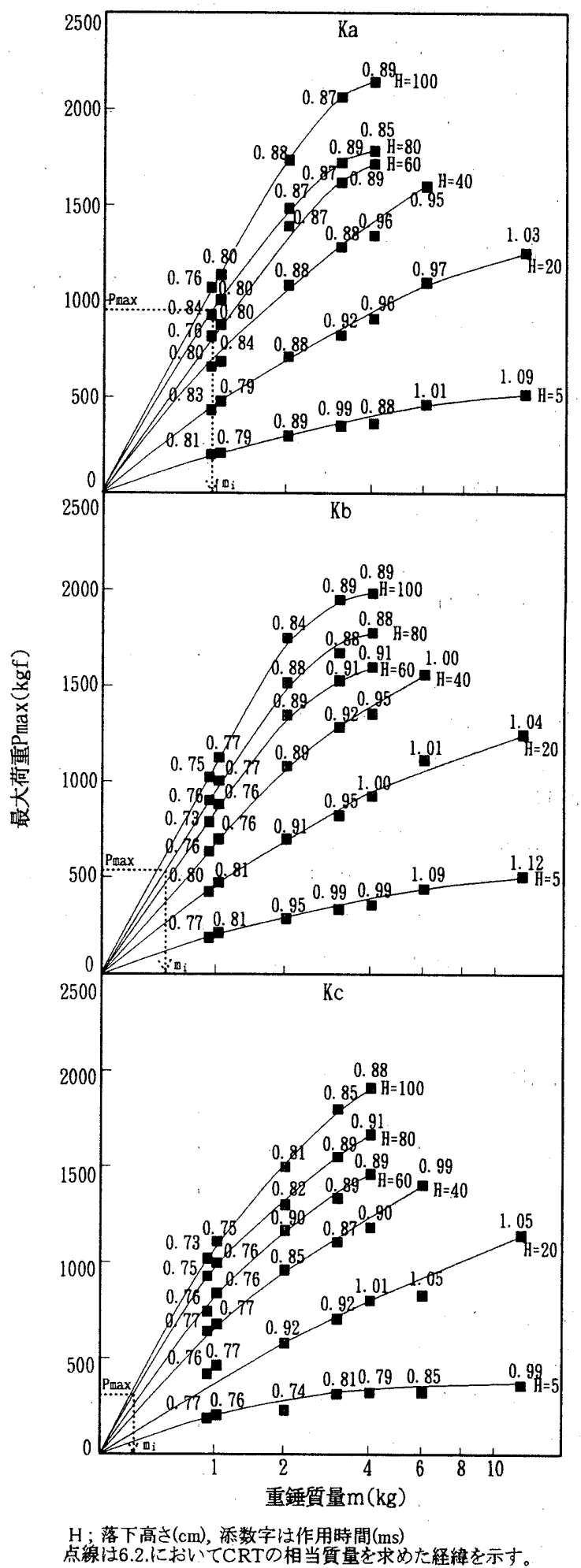

图5 重鎧筫量と最大荷重の関係

定性的に考察する上では，PとPmaxを同義とみて問題はないことを付 記する。

なお，重鍾の質量および落下高さを同一としても検出される荷重の 絶対值は荷重測定装置の㴊性, 举動部の質量などの力学的特性に より変化することが明確で4.3.で論した留意点を実証しているといえる。 さらに, $P \max の$ 作用時間 $\Delta \mathrm{t}$ はすべてを含めて0.73ms〜 $1.12 \mathrm{~ms}$ の 狭い範囲にあり，物体の場合の作用時間との近似性を検討した後明 言すべきであるが, 床の破損の観点では重要な要因として取り込む必 
要性が少ないこと,つまり最大荷重Pmaxのみを対象としてよいことも推 察できる。

以上,様々な知見を得るとともに，4.3.に述べた方法で同定するた めに必要な最大荷重Pmaxと重鍾質量mの関係を定量化できたといえ る。

\section{6. 物体による動的荷重の測定および相当質量の望出例}

6.1. 物体および落下高さの設定および測定

床に動的荷重を与える物体および落下高さ(衝突速度)の組合せは 無限にあるといえるが本論文では同定方法の骨子を提示するという観 点加

。手近にあること

。衝突時の物体側のエネルギーの吸収に差を持たせること

に留意し代表例しして表 2 に示寸物体, 落下高さおよび衝突状況を 設定した。

なお，落下高さが物体により異なっているが，予備実験から，物体が 破損する際は最大荷重Pmaxは非常に小さくなるので, 物体が破損し ない範囲で測定可能な落下高さを各々設定したものである。

測定は5. と同様の方法で行い, 最大荷重Pmaxを求めた。

ここで最大荷重Pmaxの作用時間を検討した所，すべてを含めた範 囲が0.56ms〜 $17.8 \mathrm{~ms}$ にあ, 重鍾の範囲 $0.73 \mathrm{~ms} \sim 1.12 \mathrm{~ms}$ と比較して, 幅が広くなっているが, 動的荷重の効果の観点からは架構式床の固 有振動数を考慮した共振応答などの有無の観点からみて問題となら ない差異なので, 動的荷重の効果はPmaxのみで論じてよいといえる。 6.2. 相当質量の導出

求めた最大荷重Pmaxを用い, 図5を用いて相当する重鍾質量つま り相当質量m湟求めた。

図5中に例としてCRTの相当質量を求めた経緯を点線で示す。

つぎに，物体の質量m。に対する求めた相当質量 $m_{i}$ の比，つまり相 当質量比 $\left(\mathrm{m}_{\mathrm{i}} / \mathrm{m}_{0}\right)$ を求めた。

\section{7. 考察および同定方法の提示}

図6に求めた相当質量比を荷重受板部分の剛性および落下高さと の関係として示す。

図からつぎのことが考察できる。

物体が破損しない範囲では物体の相当質量比は, 落下高さつまり 衝突速度, 荷重受板部分の剛性つまり床の剛性,にかかわらず, 物体 ごとにほぼ一定の值となる。

物体が変形しにくいほど(例えばセラミックタイル,ビール瓶など), つ まり衝突時のエネルギーの損失が少ないほど，相当質量比が大きい。

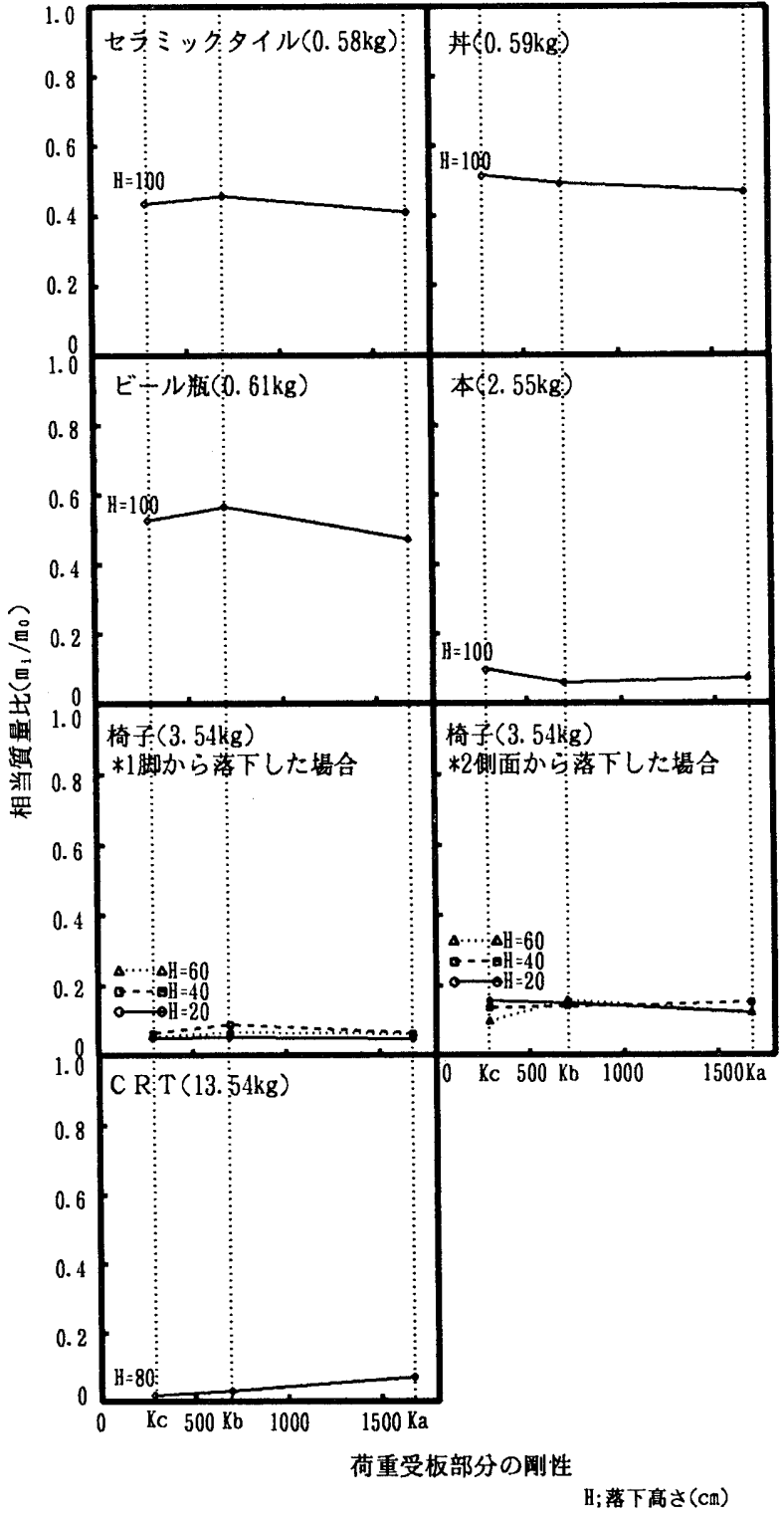

図6 相当質量比と荷重受板部分の剛性および落下高さとの関係

以上の結果は本研究の範囲でいえることであるが，物体の設定に おいて特徴的な物体を設定していることから，一般論として結論づけ ても大きな問題はないといえる。

また，以上の考察から今後の研究においては，特に過大な動的荷 重を与える物体つまり質量の大きな物体を機械的荷重体に同定する 場合図 5 の重鍾質量と最大荷重の関係, さらには, 物体による最大荷 重は荷重測定装置の能力の範囲内つまり, 非常に小さな衝突速度で 同定して問題がないこと,さらに荷重測定装置の荷重受板部分のの剛
表2 物体, 落下高さおよび床の街突状況

\begin{tabular}{|c|c|c|c|c|c|c|c|c|}
\hline & & 妨荈多㑐 & 开 & ビール瓶 & 本 & 椅子*1 & 椅子*2 & C RT \\
\hline 質量m(kg) & & 0.58 & 0.59 & 0.61 & 2.55 & 3.54 & 3.54 & 13.54 \\
\hline \multirow{3}{*}{ 落下高さH(cm) } & $\mathrm{Ka}$ & 100 & 100 & 100 & 100 & $20,40,60$ & $20,40,60$ & 80 \\
\hline & $\mathrm{Kb}$ & 100 & 100 & 100 & 100 & $20,40,60$ & $20,40,60$ & 80 \\
\hline & $\mathrm{Kc}$ & 100 & 100 & 100 & 100 & $20,40,60$ & $20,40,60$ & 80 \\
\hline \multicolumn{9}{|l|}{ 衝㔖状洗 } \\
\hline & & 797971 & DIP71711, & 17797111, & 1711 & & 771 & \\
\hline
\end{tabular}

性はひとつで同定してよいこと,な どの研究遂行上非常に有益な知 見を得ることもできる。

以上から，荷重体としての物体 の機械的荷重体への同定方法を つぎのように提示する。

1) 対象とする物体を設計・試作し た荷重測定装置に所定の条件

で衝突させて最大荷重を求める。 2)あらかじめ求めた重錘による最 
大荷重と重鍾質量の関係に, 求めた最大荷重を照合し, 相当する 重錘質量つまり相当質量を求める。

3) 求めた質量を持つ剛性重鍾を軸とする荷重体を，対象とする物体 の機械的荷重体とする。

なお，1，2），3）における衝突速度および荷重測定装置の荷重受 板部分の剛性は各々 1 条件でよい。

4) 求めた機械的荷重体を用いて床一動的荷重を負荷する場合の速 度は実情を勘案しながらのその都度の課題とする。

\section{8. 結}

物体が与える動的荷重による架構式床の破損の評価方法を確立す る重要性を述べるとともに，評価方法を確立するために必要不可欠と なる, 荷重体としての物体の機械的荷重体への同定方法を提示した。 また, 本論文において，様々な場面で問題となる近似した動的荷重 を取り扱う場合の留意点をも含めて強調したつもりである。

次稿では，様々な物体の同定資料を提示するとともに，破損を定量 的に評価するための方法を提示する予定である。

なお，結びにあたり，論文作成に協力頂いた東京工業大学技官石 澤砂月氏に感謝いたします。
<参考文献>

1) JIS A 6519 「体育館用銅製床下地銅製材

2) JIS A 1450「フリーアクセスフロア構成材試方法」

3）小野英哲,崔寿炅:休·壁に人間が与文る動的荷重の解析一人間が与える動的 荷重による架構式佅·壁の破損の評価方法に関する研究(その1)一, 日本建筑学 会構造系論文集 No.460, pp.27〜35, 1995.4

4) 小野英哲, 崔寿炅: 人間の動的荷重による架構式床·壁の破損評価試呀装置の 設計・試作一人間が与える動的荷重による架構式床・壁の破損の評価方法に関 する研究(その2)一, 日本建策学会樓造系論文集 Na.470, pp.19 28, 1995.4

5) 小野英哲, 崔寿炅, 井戸川純子:架構式床·壁の破損評価試験装置の設計·試作, 破損判定方法および破損の評価方法の提示一人間が与点る動的荷重による架構 式床・壁の破損の評価方法に関する研究(その3)一, 日本建築学会㵒造系踰文 菓 No.495, pp.15 20, 1997.5

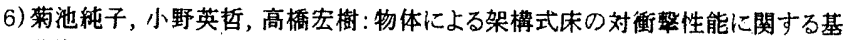
礎的検討, 日本建築学会大会学術講演梗概集A-1, pp.491 492, 1997.9

7) 宇野英隆, 咫詳治, 山本公也: 人間動作の衝繋力について, 日本建築学会踚文 報告集号外, 1967.10

8)内田祥哉, 胡占星ほか:床のかたさが人体に及ぼす影響について, 日本建策学 会論文報告集号外, 1968

9)内田祥哉, 宇野英隆, 䞦謙治, 山本公也:Building Elementに加わる衝軗力とそ の酎衝撃性能(その1)一衝撃力の分析と被撃物の举動一、日本建築学会論文報 告集 No.153, pp49〜58,1968.11

10)内田祥哉, 宇野英隆, 吳譜治, 山本公也: Building Elementに加わる衝繋力とそ の酎衝撃性能(その2)一建築の耐衝撃性能判定に対する提案一，日本建築学会 論文報告集 No.154,pp1〜8, 1968.12

11) J.Dubblin Mc Natt and Lawrence A.Soltis : 「 Instrumented Impactor for Testing Wood-Base Floor Panels $\rfloor$, JOURNAL OF TESTING AND EVALUATION, JTEVA, vol.18 No.4, July $1990, p p .265 \sim$ pp. 273 12）小野英哲, 吉岡丹:体育館の床の弾力性に関する研究(その2)一体育館の代の 弾力性测定装置の設計·試作一, 日本建築学会論文報告集 No.187, pp1 10, 1971.9

13）小野英哲, 吉岡丹:体育館の床の弹力性に関する研究(その1)一運動競技者が 休に与光る荷重の解析一, 日本建築学会論文報告集 No.181, pp7〜14, 1971.4

（1997年 7 月10日原稿受理，1998年 5 月 8 日採用決定） 